\title{
Strategies to Develop Mortgage Markets in Transition Economies*
}

\author{
Dwight M. Jaffee \\ Haas School of Business \\ University of California \\ Berkeley CA 94720-1900 USA \\ Telephone: 510-642-1273 \\ Fax: 510-649-3076 \\ Email: jaffee@haas.berkeley.edu \\ and \\ Bertrand Renaud \\ The World Bank \\ Room G-8-117 \\ 1818 H Street \\ Washington D.C. 20433
}

\begin{abstract}
* The authors would like to thank participants at the Poznan conference on Financial Markets in Emerging Market Economies (20 January 1996) and the European Financial Management Association annual meetings at Innsbruck, 27 June 1996) and especially Dr. Victor Murinde for comments on early versions of the paper.
\end{abstract}

\section{Paper Abstract}

The paper analyzes the factors that hinder the development of mortgage markets in economies that are in transition from central planning to a market system, and proposes a strategy to expedite this development. It is shown that banks in transition economies are reluctant to make mortgage loans due to the risks in mortgage lending (credit, interest rate, and liquidity risk). A secondary mortgage market (SMM) is likely to help solve this problem. A SMM separates the act of making mortgage loans (which can still be carried out by banks) from the act of holding mortgage loans (which can be carried out more effectively by capital market investors.)

Key words: mortgages, banking, transition economies, secondary mortgage market

Publication: As Chapter 4 in J. Doukas, V. Murinde and C. Wihlborg editors, Financial Sector Reform and Privatisation in Transition Economies, Elsevier Science Publications, 1997; (also published in Polish by Poznan University Press). 


\section{INTRODUCTION}

The transformation of the planned economies of central and eastern Europe to market economies has focused on three key processes:

1) economic stabilization and liberalization,

2) privatization,

3) financial sector development.

The housing sector and its financial dimension, the mortgage market, have been a factor in each of these processes, although, sad to say, not always a positive one.

The housing sector has not contributed to economic stabilization, since new housing construction in most transition economies has plummeted since 1988, as shown in Figure 1. Even if we take into account the statistical under-reporting problems for private investment activities in housing rehabilitation, it is undeniable that the withdrawal of the state from direct housing production has led to a precipitous fall in annual output. The housing sector has also lagged in terms of economic liberalization, since house rents continue to be among the most regulated prices in the transition economies. (Although some rent controls appear in many economies, they take on an extreme form in most transition economies as a legacy of central planning.)

The privatization of housing sector assets has also been painfully slow, even when housing units are available to the current occupants at virtually no cost. This may reflect, at least in part, the fear that owners will be charged higher utility and maintenance costs than are renters. In any case, this slows down the overall process of privatization since housing generally represents a large part of any country's tangible capital. In the United States, for example, residential structures (excluding land) represent almost 30\% of all tangible capital and all real estate (including land) represents almost $70 \%$ of all tangible capital (see Table 1). These ratios may be somewhat lower 
for the transition economies, but not by a large margin. This is illustrated in Figures 2 and 3 , which show the number of housing structures per 1000 population for groups of transition and developed economies respectively.

In terms of financial sector development, housing finance has remained in a primitive state compared to the rapid development of banking and other financial markets. This is particularly striking because, in most developed countries, the mortgage market--meaning the market for financing real estate assets--is among the largest components of the capital markets. In the United States, for example, mortgage debt is the largest component of the domestic debt markets (see Table 1).

Mortgage market development is likely to be a key factor in overall financial market development. In particular, an efficient mortgage market will act as a positive externality for the other capital markets, creating pressure for higher efficiency in these markets. On the other hand, a poorly functioning mortgage market is likely to "pollute" other financial markets with its inefficiency. For example, governments are likely to "support" inefficient mortgage markets with subsidies and regulations, which then act as implicit taxes and constraints on the rest of the capital markets. In fact, controlling the proliferation of quasi-fiscal subsidies is a generic problem of transition economies.

Our primary goal in this paper is to analyze the problems that are inhibiting the development of viable housing finance systems in transition economies and to draw relevant policy conclusions. Figure 4 shows graphically that housing finance is just one part of a much larger program for developing sustainable financial sectors in the transition economies. We shall refer to other components of the financial system in our discussion of housing finance. 
The rapid development of the banking sector in most transition economies raises an immediate question, namely why the banks in the transition economies have failed to take the lead in developing a housing finance system. We deal with this question in Part 2, focusing on a series of risks--credit, interest rate, and liquidity--that have constrained the ability of transition economy banks to develop housing finance systems

The slow development of mortgage markets in transition economies indicates the need to create a coherent housing finance strategy. In Part 3, we first approach this topic by evaluating the housing finance systems used in the developed economies. We contrast the two primary systems that are observed--depository institutions acting as portfolio lenders and secondary market systems. We further analyze the alternative versions of secondary market systems.

In Part 4, we evaluate the likely efficacy for the transition economies of the alternative systems used in developed economies. Our conclusions favor secondary mortgage markets as the key instrument to eliminate the constraints that have slowed the development of housing finance systems. Secondary markets confer two main benefits. First, banks can shed the risks associated with holding mortgage loans by selling the loans to other investors through the secondary market. Second, secondary markets create standards for credit evaluation and collateral procedures that directly increase the efficiency of the primary markets for new mortgage originations. Although this paper focuses on the development of secondary mortgage markets, fundamental changes are also required to develop the primary mortgage markets in the transition economies (see World Bank [1995] for a discussion of primary mortgage markets in Russia).

In Part 5, we summarize our conclusions.

[Insert here: Table 1, Figures 1 to 4$]$ 


\section{BANKING AND HOUSING FINANCE IN TRANSITION ECONOMIES}

We have seen that the rate of new housing construction in most transition economies has plummeted since 1988. This could suggest that the failure to develop housing finance systems has been the result of little demand for mortgage loans to finance new construction. The same transition economies, however, have a pent-up demand to exchange existing residential structures, either to match housing locations with job locations or for family life-cycle reasons. Such trading of existing structures generally creates a large demand for housing finance. Furthermore, the low levels of new housing construction and the value of a housing asset as an inflation hedge have raised the excess demand for housing (housing shortages), thereby creating an excess demand for housing finance. In short, there ample demand for housing finance in the transition economies. Therefore, the source of the failure to develop housing finance systems can be reasonably associated with supply side lenders, primarily the commercial banks.

We now consider a series of risks that are directly tied to the reluctance of banks to make housing finance loans. In all economies, long-term housing loans create significant credit, interest rate, and liquidity risks for bank management. In the transition economies, volatile inflation and the political pressures to control interest rates have expanded these risks even further. The financial instruments and markets that are used to manage these risks in the developed economies are just now beginning to function properly in the group of advanced reformers. The lack of credit evaluation skills and inadequate capital are other constraints to mortgage lending that are only slowly being resolved. We now look at these factors individually. 


\section{Credit Risk}

In developed mortgage markets, credit risk--that is, the risk of default--on a real estate loan is usually measured by two ratios, with a lower value of either ratio indicating less credit risk:

$>\quad$ The loan to value ratio is the ratio of the loan amount to the property value.

$>\quad$ The payment to income ratio is the ratio of the annual mortgage payment (including payments for insurance, property taxes, and the like) to the borrower's annual income.

\section{$\underline{\text { Loan to Value Ratios }}$}

The loan to value ratio is generally considered the more basic determinant of credit risk because, as long as the loan amount is less than the property value, the lender can always recover the loan principal by taking over the property and selling it. In transition economies, however, this is unlikely to be the case for two reasons. First, the property rights and foreclosure procedures that are needed for real estate to function as loan collateral are not well established in the legal and institutional structures of the transition economies. Second, accurate methods for estimating property values in transition economies are just now being developed, and this is made even more difficult by the inflationary conditions in many of these countries.

\section{$\underline{\text { Real Estate Property Rights }}$}

In most transition economies, property laws had to be rewritten to recreate the concept of real estate. Privately managing the bundle of land and building rights that constitute real estate property in a market economy is still a new way of operating. The requirements of residential and business real estate development often remain poorly understood or accepted by central and city administrations. In Russia, in particular, it is proving politically very difficult to develop the concept of private land ownership and to accept the trading of land and the emergence of land 
markets. ${ }^{1}$ The privatization of the housing stock is also incomplete. Apartments units can be privatized, but in the absence of condominium laws and the creation of condominium associations, the financing and maintenance by residents of the public space and the networks within the buildings is inadequate. Another frequent problem was, and still is, that land property boundaries were not drawn up and recorded at the time of construction under the state system. They now need to be defined and accepted by parties often suspicious of each other.

\section{Secured Lending and Real Estate}

In all transition economies, the weak environment for secured lending affects all types of loans, including loans to small and medium sized enterprises. Loans secured by real estate lending suffer especially from the legacy of poor land titling. Even in countries with a tradition of high quality registration, like east Germany, "land books" were no longer properly maintained during the socialist era. Stable and sound land use systems are emerging in a painfully slow way from the legacy of the state urban planning. Old urban plans and old urban cadres constrain the entire property sector and therefore all forms of physical investment. Incomplete and untested collateral and foreclosures laws create large credit risks for lenders. Alternative forms of collateral lending that differ from the usual Western foreclosure practices may therefore be useful.

\section{$\underline{\text { Payment to Income Ratios }}$}

In the absence of real estate as a source of dependable collateral, payment to income ratios become a more critical determinant of credit risk. In the transition economies, however, the payment to income ratio is also unlikely to provide lenders with dependable protection against loan default. The primary problem is that average income to property value ratios tend to be an order of magnitude lower in the transition economies. Specifically, in most developed economies,

\footnotetext{
${ }^{1}$ See Bertaud and Renaud [1994].
} 
the average income to property value ratio ranges from about $1 / 4$ to $1 / 3$, while in most transition economies the same ratio tends to be $1 / 10$ or lower. Although this is likely to be temporary, since it is primarily the result of highly depressed income levels in the transition economies, it makes housing loans in the transition economies extremely risky. Furthermore, the difficulty of verifying income--due to significant underground economic activity and the absence of credit bureaus-increases credit risks and leads to credit rationing.

\section{Interest Rate Risk}

In developed economies, housing finance lenders are sometimes short funded, meaning that the maturity (or duration) of their mortgage assets exceeds the maturity of their funding sources (such as bank deposits). This occurs because mortgage borrowers generally wish to match their durable housing assets with long-term mortgage loans, while depositors prefer the liquidity of short-term investments. The short funding creates an interest rate risk for the lenders, since an increase in market interest rates raises the cost of deposits without immediately raising the return on the mortgage assets. The interest rate risk can be hedged using capital market instruments, but they have a high cost, approximately equal to the difference between short-term and long- term interest rates. Alternatively, the interest rate risk can be controlled by using adjustable-rate or floating-rate mortgages, but these instruments only displace the interest rate risk to the borrower.

In the transition economies, capital market instruments are unlikely to be available to hedge the interest rate risk, so floating-rate mortgages will be the norm. This means that borrowers face the interest rate risk, which increases their likelihood of loan default. In other words, floating-rate mortgages tend to transform the banks' interest rate risk into credit risk, not necessarily a significant improvement. Furthermore, real interest rates (nominal interest rates minus the 
expected inflation rates) have been high (often in excess of 15\%) and volatile in the transition economies, further raising the credit risk on adjustable-rate mortgages.

In fact, price-level indexed mortgages, which contractually set a fixed real interest rate for the mortgage, offer a potentially better solution for controlling both interest rate and credit risk in the transition economies. There are also hybrid instruments, such as the dual interest rate mortgage (DIM) used in Mexico, which create variable, real-rate, mortgages. However, these mortgages remain relatively complex instruments, and therefore are likely to be difficult to introduce in an otherwise under-developed housing finance system.

\section{Liquidity Risk}

The depositors in transition economies are likely to value liquidity--meaning the ability to convert deposits rapidly to cash--reflecting the high risks associated with the macroeconomy, individual banks, and the consumer's individual needs for funds. The banks must therefore anticipate large and unexpected deposit outflows, which require that assets be rapidly sold to finance the deposit outflows. Government securities are good assets for this purpose, since they trade in active and liquid markets and their prices are accurately determined. Business loans are more difficult to sell, but their short-term maturities make them essentially self-liquidating. Mortgages do not have short-term maturities and they do not easily trade in secondary markets (because buyers find it costly to verify the credit quality of each mortgage offered for sale). Taking these factors together, mortgages create significant liquidity risks for lenders. 


\section{EFFICIENT MORTGAGE MARKETS IN DEVELOPED ECONOMIES}

Efficient mortgage markets require that the lending risks--credit, interest-rate, and liquidity--be allocated to the long-term investors who are best able to handle them. Many alternative systems have been used, reflecting different economic conditions and attitudes toward risk. For example, the late 19th century saw the development of what we call the mortgage credit institute (MCI), created throughout Europe and most common in Northern Europe. ${ }^{2}$ The structure of these banks reflected the tradeoff between credit risk on one hand and interest rate and liquidity risk on the other hand. Its German version (the Hypothenken Bank), for example, minimized credit risk by making mortgage loans with loan to value ratios below $60 \%$. Although this reduced the credit risk faced by the bank, it forced the borrowers to delay their first home purchase until they had accumulated the substantial equity required for the downpayment.

In the United States and England, until recently, most home loans have been made by depository institutions, including commercial banks, Savings and Loan Associations in the United States, and Building Societies in England. How the various risks are shared between the lender and borrower then depends on the particular form of the mortgage instrument. For example, in the United States during the Great Depression of the 1930s, many borrowers suffered the unexpected loss of their homes when lenders suddenly stopped renewing short-term mortgage loans. On the other hand, in the United States during the early 1980s, the Savings and Loan Associations (S\&Ls) suffered massive losses and many of the institutions ultimately failed when interest rates rose unexpectedly while the institutions were following a short funding strategy using fixed-rate mortgages.

\footnotetext{
2 See European Mortgage Federation [1990] for further background. The MCIs made mortgage loans to various borrowers including households, commercial enterprises, and local governments.
} 
A key advantage of the depository institution system is that three distinct mortgage market

functions can be vertically integrated within the depository institution:

- $\quad$ Mortgage origination is the process through which mortgage debt is created, comparable to the underwriting function for other capital market securities. ${ }^{3}$

- $\quad$ Mortgage holding refers to the activity of institutions and other investors who own or hold mortgage debt. When the mortgage originator and the mortgage holder differ, it is necessary to transfer mortgage ownership. The high risk, high information costs, and small size of individual mortgages complicate the mortgage transfer process.

- $\quad$ Mortgage servicing refers to a series of activities, including (1) collecting the monthly payments from the borrowers and transmitting the funds to the holders, (2) confirming that the borrower maintains property insurance and pays property taxes, and (3) carrying out the foreclosure process in cases of default.

The last 30 years, however, have seen a trend toward separating or unbundling these mortgage market functions. The new developments can be described as secondary market systems, in which mortgages are originated by one agent (a depository institution or specialized mortgage originator), but are then transferred to a capital market institution or other investor who serves as the final holder. In many European countries, the final holder is a mortgage credit institution, which issues its own debt. In the United States, there are two government sponsored agencies--Federal National Mortgage Association (FNMA, or Fannie Mae) and Federal Home Loan Mortgage Corporation (FHLMC, or Freddie Mac)--which purchase mortgages directly from originators. Another government agency, the Federal Home Loan Banks, lends funds to mortgage originators.

\footnotetext{
${ }^{3}$ Strictly speaking, real estate loans generally consist of two documents: the bond (or note) which documents the terms of loan repayment; and the mortgage which provides the collateral. We will follow common usage, however, in using the term "mortgage" to refer to both sets of loan documents.
} 


\section{Criteria for Evaluating Efficient Mortgage Market Systems}

The most basic indicator for evaluating alternative structures is the borrower's "all-in" cost. The all-in borrowing cost incorporates both the direct interest rate and the costs associated with the non-price terms of the mortgage instrument such as maturity, floating interest rates, downpayment requirements, and credit availability. In principle, each of the three mortgage functions--origination, holding, and servicing--can have an independent impact on the borrowing cost. In practice, however, the holding function is the primary economic factor, since the mortgage holder can then choose the most efficient institutions for administering the mortgage origination and servicing activities.

The all-in borrowing cost also includes the government's cost of guaranteeing or otherwise administering the housing finance system. For example, under the depository institution system, some of the government's costs associated with safeguarding deposits should be included in the all-in costs of the housing finance system. Under a secondary market system, the same is true for the government's cost of providing credit guarantees on mortgage instruments and/or the liabilities of the mortgage holding institutions. The government may try, of course, to deny responsibility for the housing finance system's credit risks, but this is rarely successful.

We now apply the all-in borrowing cost criteria to alternative mortgage systems. ${ }^{4}$

\section{Depository "Portfolio Lenders"}

Depository institutions acting as portfolio lenders have three key advantages as the central source of funds for mortgage lending. First, the interest rates on deposits tend to be among the lowest in an economy, reflecting the "retail" nature of this source of funds. Second, by integrating all the mortgage functions--origination, holding, and servicing--in a single institution, the 
depository system avoids the costs of transferring mortgages to other holders, an efficiency of vertical integration. Third, retail lenders may have informational advantages in extending credit to households who are also customers for other banking services.

\section{Factors Raising the All-In Costs of Depository Lenders}

A closer examination of these advantages of the depository system reveals, however, that they may be more apparent than real. First, the all-in cost of retail deposits must include the costs of hedging the interest rate risks that result from a short funding strategy. ${ }^{5}$ The all-in cost of retail deposits should also include the institutions' costs of satisfying required capital ratios and other supervisory standards, and the government's cost of insuring retail deposits.

Second, the economies of scale in mortgage origination and servicing created by recent technological innovations in computers, communications, and information retrieval appear now to dominate the economies of vertical integration that underlie the depository system. This change is evident in the innovative unbundling of mortgage functions and activities occurring in many developed countries.

Third, depository lenders often find it more profitable to apply their credit evaluation expertise to business and consumer loans than to mortgage loans. This occurs because the more complex nature of the credit risk on business and consumer loans allows the institutions to create greater value added. In addition, the maturity of most business and consumer loans is quite shortterm, so these loans do not entail the maturity mismatch discussed above for mortgages.

\footnotetext{
${ }^{4}$ For further discussion see Diamond and Lea [1992a] and [1992b].

${ }^{5}$ Alternatively, institutions may try to profit from a short funding strategy, but they then bear the risk of an occasional disaster.
} 


\section{$\underline{\text { Specialized Depository Lenders }}$}

The high all-in costs of mortgage lending by depository intermediaries often makes the activity unprofitable, which is the basic reason why banks often do not participate in housing finance. To deal with this, governments were often tempted to create a specialized depository group dedicated to mortgage lending. The Savings and Loan Associations (S\&Ls) in the United States and the Building Societies in England are examples of this approach. To maintain their special status, these institutions were required to maintain the greater part of their assets in home mortgages. In exchange, they received tax benefits and lower capital requirements. They were also allowed to follow a short funding strategy.

Specialized lenders, however, often create as many problems as they solve. In particular, since they are not well diversified across asset categories and are likely to follow a short funding strategy, they tend to be fragile with respect to changes in the economic environment. Specialized institutions also tend to avoid competition and to lag in introducing new technologies. In the United States, for example, the sharp increase in interest rates during the early 1980s created large losses for these S\&Ls, resulting in large-scale failures. Currently, regulations are being developed to transform the remaining S\&Ls into commercial banks, thereby eliminating this class of specialized lenders. Comparable changes are now occurring in the British Building Societies.

\section{Conclusions Regarding Commercial Banks as Housing Finance Lenders}

The private commercial banks in transition economies are a natural starting point to initiate a housing finance system, based on their low-cost deposits, expertise in lending, and access to retail customers. ${ }^{6}$ In practice, however, there has been very little mortgage lending by transition economy banks, because the activity is not profitable once the all-in costs are considered. 
Governments could revert to a subsidized set of specialized depository lenders, but the experience in developed economies suggests this is likely to be expensive and inefficient.

\section{Secondary Mortgage Market (SMM) Systems}

We have seen that the mortgage holding function is the strategic focus for dealing with the risks of mortgage lending. We now consider secondary mortgage markets (SMMs) as a solution for handling risk in the housing finance system . The basic principle of a SMM is to tap capital market investors as the long-term funding source for the mortgage market, thus mitigating interest rate and credit risk. Mortgages are first originated by depository institutions or other mortgage bankers $^{7}$ who are expected to have expertise in risk evaluation and underwriting new mortgage loans. The mortgages are then sold to the final investors who hold the mortgages. There are various forms for SMM systems, based on differences in the instruments used for the mortgage sale and in the type of investors or institutions who buy the mortgages.

\section{The Problems of Selling Existing Mortgages}

The SMM buyer of existing mortgages faces asymmetric information in that the mortgage seller is likely to have much better information regarding the credit risk of the underlying mortgages than does the buyer. This creates the moral hazard risk that the seller may claim that the mortgages are of high quality, whereas in fact they are of low quality. Furthermore, the low quality of the mortgages may not be revealed until many years later when higher than expected default rates begin to occur. At that time, it may also be difficult to determine whether the high default rates result from low quality mortgages or simply bad luck (high default rates on high

6 Most transition economies have also inherited a set of savings banks from their socialist era. These banks dealt exclusively with the household sector, and developed little skill in credit evaluation. 
quality mortgages $)^{8}$. As a result, most buyers of mortgages impose conditions or otherwise take actions to control these effects of asymmetric information.

One solution, for example, is for the buyer to evaluate the quality of the mortgages with the same level of diligence carried out by the mortgage originator (i.e. the mortgage seller), thereby eliminating the informational asymmetry. ${ }^{9}$ This process, however, is cumbersome and costly, since individual mortgages are of small size relative to investor portfolios and each mortgage must be evaluated. As a result, mortgage sales are rarely based on a re-evaluation of the individual mortgages. Instead, asymmetric information is controlled through a number of devises, including underwriting standards, reputation of the seller, and credit guarantees. These are now briefly described.

Underwriting Standards. The SMM buyer can specify that the mortgages meet certain underwriting standards, such as maximum values for the loan to value ratio or income to payment ratio. Of course, reporting problems still make underwriting standards an imperfect solution to the asymmetric information problem. Nevertheless, in the case of unexpectedly high default rates, the buyer may be able to claim restitution by documenting a violation of the agreed upon standards.

Reputation. In practice, most SMM buyers "prequalify" mortgage originators from whom they expect to purchase mortgages. If a SMM seller anticipates many transactions with a buyer, then the seller may not take advantage of his superior information in order to protect his reputation. The reliance on reputation is most effective for buyers with a dominant market position, since the sellers will anticipate future transactions and attempt to maintain a high reputation.

Credit Guarantees. The buyer may require that there be guarantees on the mortgages sold. When the SMM seller has a high credit rating, it can provide the credit guarantee directly. Often, however, the credit rating of the SMM seller will not be that high, and it will have to rely on external guarantees from third-parties, including the government. Such third party guarantees may apply either to the selling institution or to the individual mortgages. Purchases by Mortgage Credit Institutions

\footnotetext{
7 The term mortgage banker is used here to refer to institutions which specialize in originating new mortgages. It should not be confused with mortgage credit banks, which specialize in holding mortgages purchased from mortgage bankers.

8 The fact that "seasoned" (long outstanding) mortgages have a lower default rate is observed in all existing mortgage systems.

9 This is exactly the method used by many venture capitalists and investment bankers when evaluating investments in new start-up companies.
} 
In many developed countries, the SMM is dominated by large institutions which specialize in either purchasing mortgages or in lending funds to the institutions that hold the mortgages. Examples include the Federal National Mortgage Association (FNMA) in the United States and the Stadshypothek in Sweden.. Bond issues in the capital markets are the principal funding source for the institutions. The large size of these institutions allows them to set underwriting standards and to rely on the sellers' reputations. The large scale of their bond issues and their continuing presence in the capital markets also provides liquidity benefits that result in lower interest rates. The interest rates paid by these institutions are generally very close to the rates on government securities of the same maturity, reflecting little or no risk premium, because investors treat the bonds as if they had an implicit government guarantee. The basis for this belief is either that the government would not allow a primary component of the mortgage market to fail and/or that the institution is too large a component of the overall financial markets to be allowed to fail.

The FNMA institution provides a useful case study for how such institutions are created and the role they play in the mortgage market. FNMA was started as a government agency to create a secondary mortgage market, meaning that it was to provide liquidity by standing ready to buy and sell mortgages. In practice, FNMA primarily bought mortgages, accumulating a large and profitable portfolio (given its low cost of borrowing). At a later date, FNMA was reorganized as a stockholder-owned corporation, although the government retained some control. Most recently, FNMA has served, in addition, as a conduit for securitized mortgages (see discussion below). Another secondary market institution, the Federal Home Loan Mortgage Corporation (commonly called Freddie Mac), operates in a very similar fashion. The government imposes capital ratios on both institutions, although the requirements are approximately one-half those imposed on 
commercial banks. The two institutions dominate those parts of the mortgage market in which they are allowed to operate.

A recent paper by Hermalin and Jaffee [1996] evaluates the implicit U.S. government guarantee of FNMA and Freddie Mac $(\mathrm{F} \& \mathrm{~F})$ debt and carries out a welfare analysis of the effects of removing the guarantee. The evidence suggests that the implicit government guarantee creates an interest cost saving on the order of 50 basis points, which appears to be shared between F\&F shareholders and the country's mortgage borrowers. The country's taxpayers, however, bear the cost of the F\&F subsidy, in the form of incrementally higher government borrowing costs and the potential costs of a F\&F bailout. Overall, Hermalin and Jaffee conclude that a removal of the implicit government guarantee would be welfare enhancing, although it remains an open question whether the government could credibly shed its implicit guarantee given the importance of F\&F in both the mortgage market and the overall capital markets.

\section{Loans by Mortgage Credit Institutions (MCIs)}

MCIs can also support the mortgage market by lending funds to depository institutions who then hold the mortgages. The Federal Home Loan Banks (FHLBs) in the United States and the Caisse de Refnancement Hypothequaire $(\mathrm{CRH})$ in France operate in exactly this manner. Under this system, the MCI bears the risk of bankruptcy of the institution to which it makes the loans, but bears no direct risk with regard to the mortgages held by the institution. In practice, however, the MCI will generally hold mortgages of the borrowing institution as collateral to back its loans, so that the MCI will suffer losses only as a result of the default risk on the mortgages held as collateral. The overall effect on the mortgage market are likely to be very similar whether the MCIs buy the mortgages or advances loans to another institution to hold the mortgages, although the precise form of the risk borne by the MCI is potentially different. 


\section{Mortgage Securitization}

Mortgage securitization, a third form for the SMM, has developed very rapidly in the United States and is used occasionally in Europe. The process begins with the MCI purchasing mortgages from an originator in the same manner described above. The purchased mortgages are then combined to form a mortgage pool and prorated shares in the cash flow of the mortgage pool are sold to investors as mortgage securities. The mortgage pool and the mortgage securities are thus directly linked, and neither appears on the balance sheet of the MCI.

In the traditional mortgage purchase model described above, in contrast, the purchased mortgages and the issued bonds both appear on the MCI's balance sheet. This difference is less important than it may appear, however, since under the securitization system the MCI continues to guarantee the mortgage securities against losses created by defaults on the underlying mortgages. A more important difference is that unexpected timing variations in the cash flow from the mortgage pool, created by early repayments on the mortgages, are passed through to the mortgage security investors, whereas they are not when the MCI issues regular bonds. A more detailed discussion of mortgage securitization is provided in Jaffee and Renaud [1995]. We shall not discuss mortgage securitization further in this paper, because the refinements offered by mortgage securitization are unlikely to be relevant in the context of the transition economies. 


\section{SECONDARY MORTGAGE MARKETS IN TRANSITION ECONOMIES}

SMMs can aid the development of a housing finance system in a transition economy by removing the risks of holding mortgages from the commercial banks or others who originate the mortgages. In this section, we discuss the principles that should be applied in organizing the SMM and the issues that are likely to arise in the process. We take as the basic format a single mortgage credit institution (MCI) that will purchase mortgages from the institutions originating the mortgages, although we will also discuss alternative frameworks. The funding source of the MCI would be bonds of various maturities issued in the capital markets.

\section{The Essential Role for Government in Organizing a Secondary Mortgage Market}

The question can be asked, if a SMM helps create an efficient housing finance system, then why do the private commercial banks not create the MCI themselves. The short answer is that the MCI must have a high enough credit rating to issue bonds in the capital markets, and B rated commercial banks basically cannot create A rated MCIs. Furthermore, the MCI requires stature and size to set standards for the entire mortgage market, and it is hard for private market institutions to cooperate in order to cover the large initial costs required to set up such an institution. In particular, a fully private MCI would likely be initially too small to achieve the liquidity benefits that arise from issuing large amounts of securities on a continuing basis.

A well functioning mortgage market, however, provides enormous external benefits to the economy, including capital market development, increased labor market mobility, construction sector employment, and the efficient allocation of real estate assets. Initial government support of the SMM is therefore likely to be both essential and beneficial, which is why governments have always helped to create the MCIs in the developed economies. At the same time, the experience 
gained in creating SMMs in the developed economies can be usefully applied by the new transition economies.

\section{The Form of Government Support for a Secondary Mortgage Market}

We now analyze some specific principles that can help guide a government toward providing efficient support of the SMM. We assume that the SMM takes the form of a MCI which issues debt in the capital markets and uses its funds to purchase mortgages from the private market institutions that originate them. In the initial stages, the government should share ownership with private market participants, with each side contributing to the MCI's equity capital. International organizations, such as the International Finance Corporation (World Bank) might also contribute equity capital to the MCI. This has the further advantage that such international organizations would also contribute expertise and management experience .

\section{$\underline{\text { Government Guarantees of Mortgage Credit Institute Debt }}$}

The government's primary role in the secondary mortgage market is to guarantee the bonds issued by the MCI. This guarantee should be explicit. It is inefficient to use implicit guarantees because the government remains obligated, but the MCI does not receive the full benefit.

Furthermore, the government should charge the MCI a userfee, to defray the cost of the guarantee. This makes the amount of the subsidy transparent, and also provides an incentive for the MCI to eliminate the guarantee at a later date when it can generate a high credit rating based on its own assets and management skills. At the same time, if the government chooses to introduce other direct subsidies for housing construction or home purchase, these should be handled within the government budget or with special donor programs, not through the SMM.

\section{$\underline{\text { Level Playing Field for All Lenders and Borrowers }}$}


The goal is to create an effective housing finance system, not to support any specific class of lenders or borrowers. ${ }^{10}$ Therefore, access to the SMM should be available to all lenders and borrowers who are able to offer properly underwritten mortgage instruments for sale. In this way, those private sector institutions that are most efficient in making mortgage loans and using the SMM would be encouraged to do so, without the need for any central agency to prejudge which specific institutions will participate. This criterion seems particularly important given that most transition economies are adopting universal banking systems, in which competition and efficiency will determine which individual banks choose to specialize in each form of lending.

\section{Government Regulation, But Not Government Management}

In the transition economies, as in the developed economies, government is unlikely to manage financial institutions efficiently. Therefore, even if the ownership of the MCI is shared between the government and private banks, the banks should be the managers. ${ }^{11}$

The government, of course, should maintain an important supervisory role, reflecting its stake in the guarantees it provides on mortgages and the institutions operating in the SMM. In particular, it should set regulations specifying the type of mortgage assets purchased and bond liabilities issued by the MCI. Furthermore, it should specify required capital ratios and related supervisory standards for the MCI on a basis comparable to its commercial bank requirements. ${ }^{12}$

\footnotetext{
${ }^{10}$ Government budget fiscal subsidies should be used if certain social groups are deemed to require special help.

11 In other words, the agency cost of mixing private management with government ownership is likely to be less than the cost of inefficient government management.

${ }^{12}$ For this reason, the agency to supervise the MCIs should be the same agency that supervises the commercial banks, which, in most cases, will be the country's central bank.
} 


\section{Competition, Privatization, and Sunset Provisions}

As the housing finance system develops, the MCI is likely, sooner or later, to become quite profitable. It is therefore worthwhile to anticipate, even from the beginning, how the system should evolve. For one thing, as soon as it becomes practical, charters should be provided for the entry of additional and competitive MCIs. Otherwise, a single MCI will use its monopoly power to maximize profits, to the detriment of the housing finance system. For another thing, procedures should be established to allow the private owners of the MCI to purchase the government's share, leading eventually to a fully privatized institution. This principle was used in the United States, for example, to organize the Federal Home Loan Bank System. To remove any ambiguity whether privatization will occur, it can be useful to set a sunset date, by which the government's participation must be fully eliminated. As an example, the French government provided guarantees for only 4 years when it created a privately owned SMM institution.

\section{$\underline{\text { Public Policy in Support of Primary Lenders }}$}

Although our discussion has focused on secondary mortgage markets as a mechanism to allocate the risks of mortgage holding, a well functioning mortgage market also requires an efficient system for mortgage originations in the primary market. The institutions to carry out the primary mortgage functions are likely to arise naturally once the secondary market is established. However, the government must first take on the responsibility to create the legal and financial infrastructure-- real estate property rights, foreclosure procedures, and secured lending laws--that are the necessary first step for the development of any meaningful mortgage market activity. 


\section{CONCLUSIONS}

A housing finance system is an essential component of the development of an efficient financial system in a transition economy. Given the importance of real estate's a share of all the tangible capital in a country, and the potential for real estate collateral to secure large mounts of secured debt, the housing finance system should become an engine of innovation for the rest of the financial sector. On the other hand, if the housing finance system is stunted, then other non-market devices will develop for financing and subsidizing the housing sector, creating negative externalities for the rest of the financial system.

A housing finance system, however, is unlikely to spring up without government support, whatever one's faith in the dexterity of Adam Smith's invisible hand. Government support was required in the developed economies, and it is required now in the transition economies. In fact, the transition economies face the additional major hurdle that they must first create an economic and legal infrastructure that can support the long-term and complex market relationships and contracts that constitute a housing financial system.

We have seen in Figure 4 that the creation of a housing finance system is an integral component of the overall development of the financial sector. We also noted in the introduction that the transformation of the previously planned economies should focus on three key processes: (1) economic stabilization and liberalization, (2) privatization, and (3) financial sector development. The development of a housing finance system should reflect this sequencing, since a mortgage market can be included as a core component in step (3) only after meaningful progress has first occurred in steps (1) and (2). 


\section{REFERENCES}

Bertaud, Alain, and Bertrand Renaud, 1994. Cities Without Land Markets, Lessons of the Failed Socialist Experiment, World Bank Staff Discussion Paper 227.

Caprio, Gerard, David Folkerts-Landau, and Timothy Lane, 1994. Building Sound Finance in Emerging Market Economies, International Monetary Fund and World Bank.

Diamond, Douglas and Michael Lea, 1992a, Housing Finance in Developed Countries: An International Comparison of Efficiency, Journal of Housing Research, 3,1.

Diamond, Douglas and Michael Lea, 1992b, The Decline of Special Circuits in Developed Country Housing Finance, Housing Policy Debate, 3,3.

European Mortgage Federation, 1990, Study of European Mortgage Markets, Brussels.

Hermalin, Benjamin and Dwight Jaffee, 1996, The Privatization of Fannie Mae and Freddie Mac: Implications for Mortgage Industry Structure, U.S. Department of Housing and Urban Development.

International Securitization Report, 1995, IFR Publishing, Aldgate House, 33 Aldgate High Street, London EC31DL

Stone, Charles A. and Anne Zissu, 1994, The French Secondary Mortgage Market, Housing Finance International March, 15-21.

Weiss, Richard, 1991, A Primer on French Mortgage-Backed Securities, in Charles A. Stone, Anne Zissu and Jess Lederman, Asset Securitization: Theory and Practice in Europe, Euromoney.

Titrisation: en attente du démarrage Paris Crédit Foncier de France: L' Observateur Immobilier No.30 February 1995

World Bank [1995], Country Report No. 14929-RU, "Russia Housing Reform and Privatization: Strategy and Transition Issues." 


\begin{tabular}{|c|l|l|l|}
\hline \multicolumn{4}{|c|}{ Table 1 } \\
\multicolumn{3}{|c|}{ U.S. Tangible Capital Assets and Debt Instruments, Year-End } \\
\hline & Tangible Capital Assets & \$ Trillion & Percent \\
\hline 1 & Residential Structures & 5.5 & 29 \\
\hline 2 & Non-Residential Structures & 3.0 & 16 \\
\hline 3 & Land & 4.2 & 23 \\
\hline 4 & Total Real Estate (1+2+3) & 12.7 & 68 \\
\hline 5 & Total Tangible Capital & 18.7 & 100 \\
\hline & Debt Instruments & & \\
\hline 6 & Mortgages & 4.2 & 34 \\
\hline 7 & U.S. Government & 3.4 & 27 \\
\hline 8 & Corporate Bonds & 1.2 & 10 \\
\hline 9 & State and Local Government & 1.2 & 10 \\
\hline 10 & Total Debt & 12.4 & 100 \\
\hline & Source: Flow of Funds, Federal Reserve Board & \\
\hline
\end{tabular}


FIGURE 1: Collapsing Output of Completed Dwellings

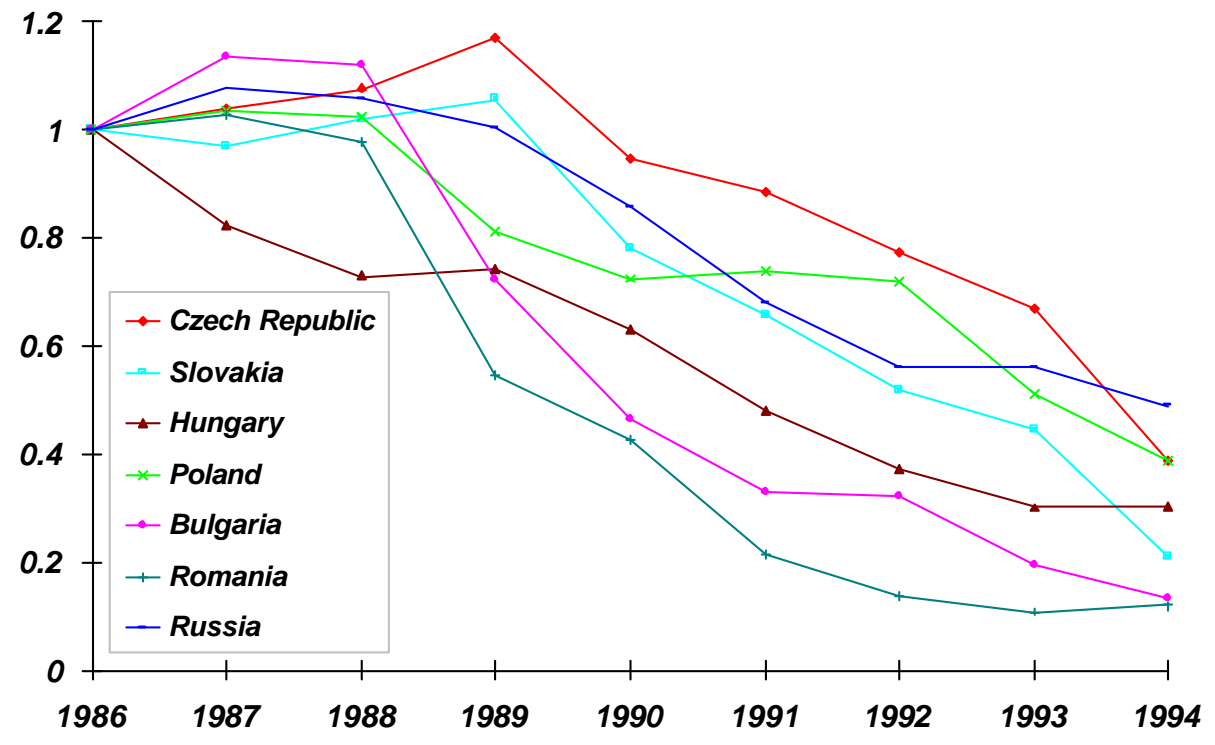


FIGURE 2: Housing Stock in Transition Countries, 1991

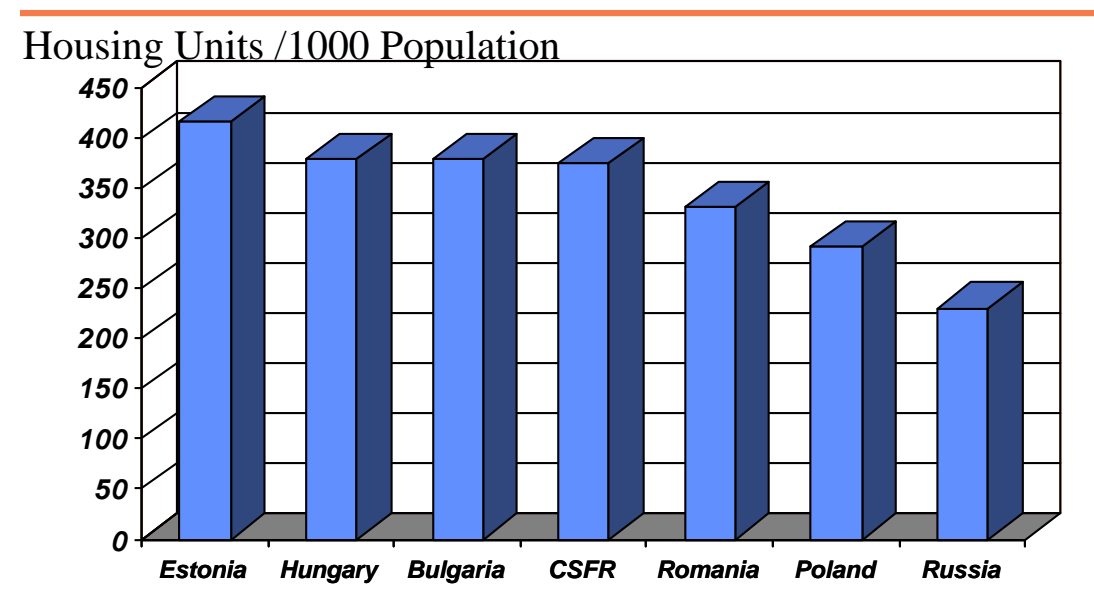

Source: UN-ECE, Annual Bulletin of Housing \& Building Statistics, November 1994 
Figure 3: Housing Stock in Developed Countries, 1990

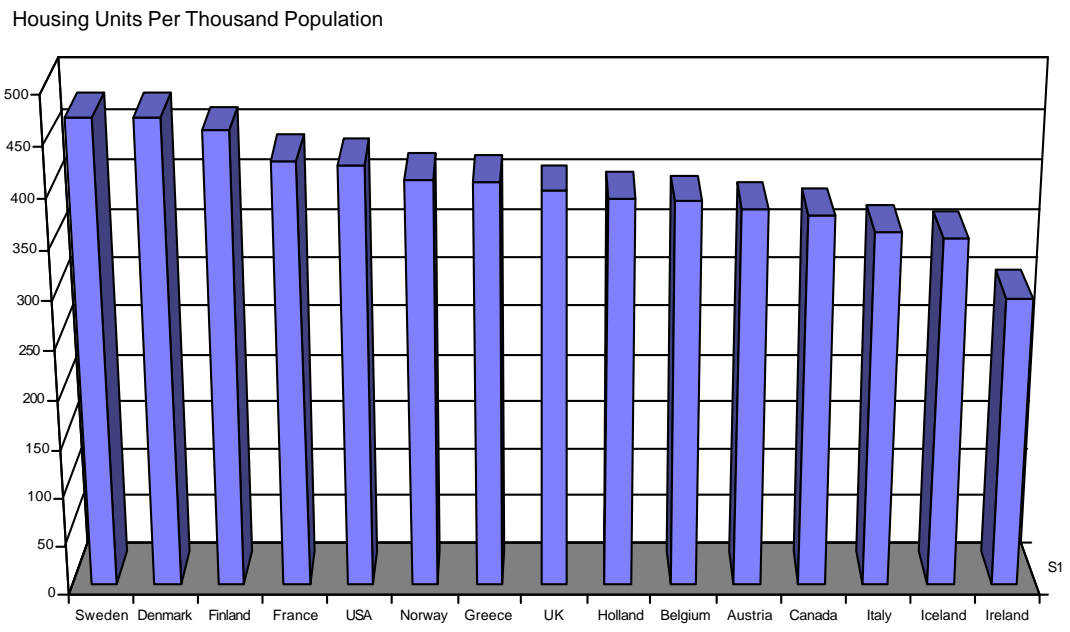


Figure 4: A Framework for Sustainable Financial Development

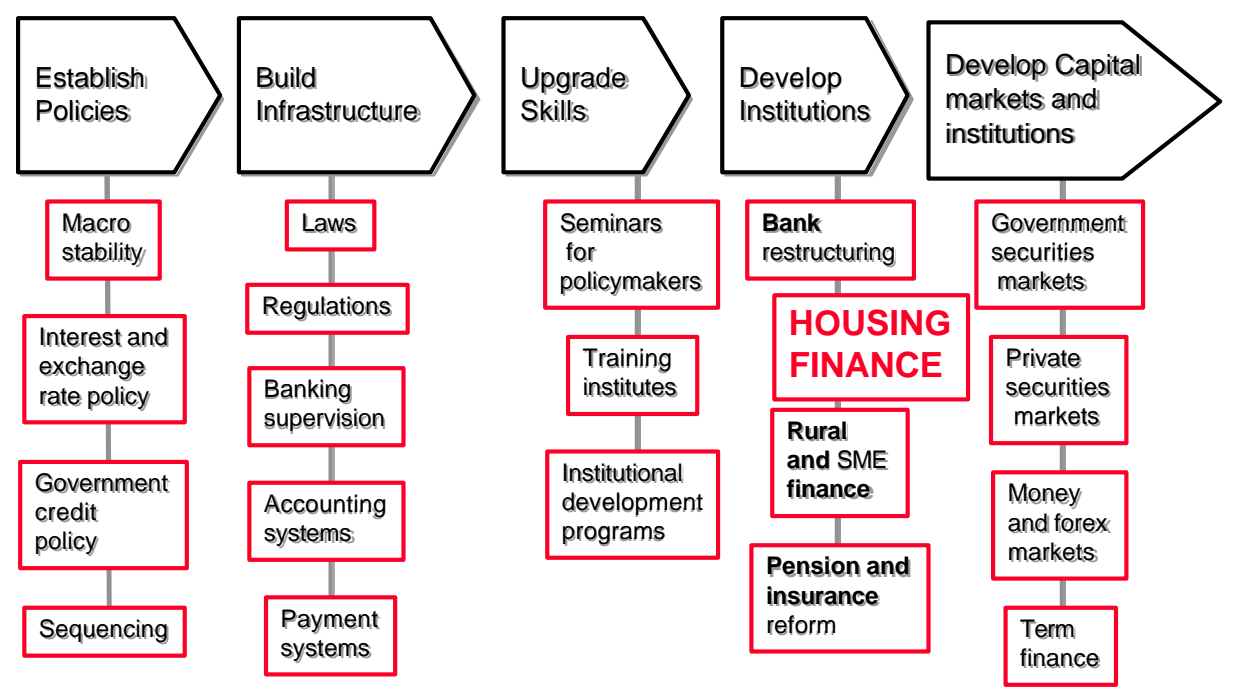

